\title{
Microhabitat of small mammals at ground and understorey levels in a deciduous, southern Atlantic Forest
}

\author{
GERUZA L. MELO ${ }^{1,2}$, BARBARA MIOTTO ${ }^{2}$, BRISA PERES $^{3}$ and NILTON C. CÁCERES ${ }^{2}$ \\ ${ }^{1}$ Programa de Pós-Graduação em Ecologia e Conservação, CCBS, \\ Universidade Federal do Mato Grosso do Sul, Caixa Postal 549, 79070-900 Campo Grande, MS, Brasil \\ ${ }^{2}$ Laboratório de Ecologia e Biogeografia, Departamento de Biologia, \\ Universidade Federal de Santa Maria, Camobi, 97110-970 Santa Maria, RS, Brasil \\ ${ }^{3}$ Programa de Pós-Graduação em Biologia de Ambientes Aquáticos Continentais, \\ Universidade Federal do Rio Grande, Av. Itália, Km 8, Campus Carreiros, \\ Caixa Postal 474, 96201-900 Rio Grande, RS, Brasil
}

Manuscript received on June 13, 2012; accepted for publication on January 10, 2013

\begin{abstract}
Each animal species selects specific microhabitats for protection, foraging, or micro-climate. To understand the distribution patterns of small mammals on the ground and in the understorey, we investigated the use of microhabitats by small mammals in a deciduous forest of southern Brazil. Ten trap stations with seven capture points were used to sample the following microhabitats: liana, fallen log, ground litter, terrestrial ferns, simple-trunk tree, forked tree, and Piper sp. shrubs. Seven field phases were conducted, each for eight consecutive days, from September 2006 through January 2008. Four species of rodents (Akodon montensis, Sooretamys angouya, Oligoryzomys nigripes and Mus musculus) and two species of marsupials (Didelphis albiventris and Gracilinanus microtarsus) were captured. Captured species presented significant differences on their microhabitat use (ANOVA, $\mathrm{p}=0.003$ ), particularly between ground and understorey sites. Akodon montensis selected positively terrestrial ferns and trunks, S. angouya selected lianas, D. albiventris selected fallen trunks and Piper sp., and G. microtarsus choose tree trunks and lianas. We demonstrated that the local small-mammal assemblage does select microhabitats, with different types of associations between species and habitats. Besides, there is a strong evidence of habitat selection in order to diminish predation.
\end{abstract}

Key words: cricetid rodents, didelphid marsupials, habitat selection, predator-prey relationship, vertical space use.

\section{INTRODUCTION}

Niche can be defined as an n-dimensional hypervolume where each dimension corresponds to distinct environmental conditions that define the environment limits where the species persists

Correspondence to: Geruza Leal Melo

E-mail: geruzalm@yahoo.com.br
(Hutchinson 1957), being this space limited according to interactions with other organisms. In this sense, the adaptation to different types of available resources in an environment can promote the differentiation and coexistence of a wide range of species, resulting into an increased diversity (Wells et al. 2006). Between the factors that 
promote the coexistence, the spatial segregation is one of the most important (Schoener 1974). Microhabitats are discrete portions of the available space that meet those niche requirements, and have been described in terms of environmental variables that directly or indirectly affect individual behavior, determining which parts of an area within the home range are more heavily used (Morris 1987a). Knowledge of the microhabitat selection allows us to understand the causes of the spatial distribution and abundance of organisms in a certain space and time (Stapp 1997, Hodara and Busch 2010). Many factors, including the availability of shelter, food, nesting sites, the abundance of competitors, the predation risk, parasitism, and disease contribute to the process of habitat selection (Rosenzweig 1981, Morris 1987, Falkenberg and Clarke 1998).

Schoener (1974) suggested that habitat segregation is more important than diet or daily activity in resource partitioning. Some studies have shown that for the small mammals, sympatry may be made possible by distinct periods of activity (Graipel et al. 2003a, Oliveira-Santos et al. 2008), food requirements (Campos et al. 2001, Cáceres et al. 2002) and the differential use of vertical space in forests (Vieira and Monteiro-Filho 2003, OliveiraSantos et al. 2008). However, most studies suggest that the selection of distinct habitats is the most important mechanism that allows species of small mammals to coexist (Price 1978, Dalmagro and Vieira 2005, Freitas et al. 2005). Therefore, analyses of space use patterns are a central requirement to infer competitive relationships and mechanisms of coexistence among species of this group (Cunha and Vieira 2004).

Microhabitat selection by small mammals has been frequently discussed in research on the Atlantic forest in Brazil, but most of the existing studies have been done in the southeast region (Freitas et al. 1996, Gentile and Fernandez 1999). Few studies have been carried out in the southern limit of this biome (Dalmagro and Vieira 2005). These investigations have been limited to microhabitat utilisation by terrestrial species, focusing only on the use of horizontal space. This is a general tendency for studies of microhabitat selection of small mammals in the Neotropics (Murúa and González 1982, Suárez and Bonaventura 2001, Vieira et al. 2005), and refined studies on vertical space use have been mostly ignored. Therefore, for Neotropical small mammals, several questions remain: What are the most selected microhabitats in the understorey? Is there differential use of lianas or tree trunks in the understorey? On the ground, are sites with fallen logs or litter used more than those where small terrestrial ferns predominate? Which small-mammal species are involved in this microhabitat selection?

Due to lack of knowledge and details about microhabitat utilisation by small mammals of the deciduous Atlantic forests in southern Brazil, this study aimed to analyse microhabitat selection not only by terrestrial small mammal species, but also by scansorial and arboreal ones, assessing the existence of selectivity for different microhabitats at the ground and understorey levels of the forest. We hypothesised that the small-mammal community shows spatial segregation, with some species using certain microhabitats more frequently than others in order to reduce competition, optimize foraging and/ or avoid predation, not only at the ground level, but also at the understorey.

\section{MATERIALS AND METHODS}

STUDy AREA

The study was conducted on the hill "Morro do Elefante", Santa Maria municipality, Rio Grande do Sul state, southern Brazil (29 40' S, 53 43' W). This is a deciduous forest area on the slopes of the Serra Geral mountain range, with a mean elevation of $110 \mathrm{~m}$ above sea level. The area contains several popular hiking trails because it is near the urban area of Santa Maria. However, the forests adjacent 
to these trails are seldom or never visited. The area adjoins a continuous forest that ranges east to west along the Serra Geral. The Morro do Elefante area has a heterogeneous floristic composition, with 67 tree species belonging to 30 plant families, mainly Leguminosae, Lauraceae, Myrtaceae, and Meliaceae (Machado and Longhi 1990).

The climate is subtropical humid temperate (Cfa according to the Köppen classification) (Moreno 1961), with rainfall evenly distributed year-round. The mean temperature during summer is higher than $22^{\circ} \mathrm{C}$, and during winter ranges from $-3^{\circ} \mathrm{C}$ to $18^{\circ} \mathrm{C}$ (Lorenzi 2002).

\section{ANIMAL TRAPPING}

Ten trap stations, each covering a $10-\mathrm{m}$ radius from a central point were established in the study area. At each station, four and three traps were distributed on the ground and in the understorey (1.5 to 2 $\mathrm{m}$ height above the ground) respectively, in the following microhabitats: fallen log with diameter at breast height $(\mathrm{DBH})>25 \mathrm{~cm}$; terrestrial ferns; ground litter without seedlings or ferns; Piper sp. shrub with the trap installed on the ground next to its stem (to test whether the presence of this fruiting plant is important in determining the habitat use and attraction by small mammals (see e.g., Cáceres 2002, Casella and Cáceres 2006); liana connected to the understorey and canopy, with no connection to the ground; simple-trunk tree $(\mathrm{DBH}>30 \mathrm{~cm})$; forked tree $(\mathrm{DBH}>30 \mathrm{~cm})$.

The minimum distance between two consecutive trap-station centers was $50 \mathrm{~m}$. We believed that this distance was sufficient for the replicates (stations), because small mammals have small home ranges (Bergallo 1990), except for the opossum Didelphis albiventris. Individuals were marked (see below) to test if the distance between sampling units was sufficient. If recaptures in the adjacent trap stations were high, this would indicate that the replicate set was not appropriate.
All capture points were uniformly distributed within the stations, with a minimum distance of 10 $\mathrm{m}$ between them and depending on the availability of microhabitats within them. We used wire-mesh live-traps (size $30 \times 12 \times 12 \mathrm{~cm}$ ) baited with bacon and peanut butter.

The fieldwork was conducted for eight consecutive days in September and December 2006, February, April, June, and July 2007, and January 2008, totaling a sampling effort of 3,920 trap-nights.

The animals captured were marked with numbered ear-tags (Band and Tag Co.), and for each individual captured the following data were recorded: species, location of capture and tag number. We collected only first records of a species in the study area, or individuals found dead in traps due to cold or rain. These specimens were deposited as vouchers in the Universidade Federal de Santa Maria (UFSM) Museum in the city of Santa Maria (numbers 394, 395, 396, 527, 528 and 529), state of Rio Grande do Sul, Brazil. The nomenclature is according to Wilson and Reeder (2005), with the addition of Weksler et al. (2006) for the "Oryzomys complex".

\section{ENVIRONMENTAL MEASUREMENTS}

In traps placed on the ground, we measured the mean litter weight (in g) and made direct counts of seedlings and ferns. In an area of $1 \mathrm{~m}^{2}$, litter was collected and weighed at two points $(1 \mathrm{~m}$ east and west regarding the position of each livetrap), and the number of seedlings and ferns was counted on two perpendicular transects of $4 \times 1 \mathrm{~m}$ (their intersection was positioned at the live-trap location). These environmental variables were measured only once at each trap station in the same period of the year.

\section{DATA ANALYSIS}

Differences in microhabitat selection between species were tested through one-way ANOVA via 
randomisation. The test involved 1,000 iterations (Monte Carlo statistic), after calculation of the Euclidean distance as a resemblance measure between the 10 sample units (Pillar 2006). The radomisation tests are robust as the parametric ones but free of assumptions of normality and homoscedasticity. The dependent variable corresponded to the number of captures by microhabitat (factor) for each species at each trapping station (replicates). Subsequently, a Correspondence Analysis (CA) was used to visualize the relationships among species and microhabitats used, and the first two axes of ordination were considered.

To assess if the environmental variables (litter, ferns, and seedlings) differed between microhabitats at ground level, we used the Kruskal-Wallis test. This test would show the main microhabitat predominating on the ground, since we were only visually oriented for that choice in the field. For example, this analysis would show if a microhabitat previously classified as dominated by "ferns" really contained more ferns.

To assess patterns of similarities and segregation in habitat selection by species in the assemblage, and also to examine if the largest species (D. albiventris) could be selecting locations where its potential prey (small rodents and marsupials) might be present, Pearson's correlation analyses were carried out, setting captures as variables and microhabitats as sampling units.

The ANOVA was performed using the statistical software Multiv Version 2.4 (Pillar 2006), and CA, Kruskal-Wallis and Pearson's correlation analyses were performed through the software PAST (Hammer et al. 2001). We used a significance level $(\alpha)$ of 0.05 for all tests.

\section{RESULTS}

We obtained 145 records of 83 individuals of small mammals belonging to four rodent species: Akodon montensis (Thomas, 1913), Sooretamys angouya (Thomas, 1913), Oligoryzomys nigripes (Olfers,
1818) and Mus musculus (Linnaeus, 1758), and two marsupial species: D. albiventris (Lund, 1840) and Gracilinanus microtarsus (Wagner, 1842). There were no recaptures in adjacent sampling units for any species except $D$. albiventris (three individuals), the largest species, showing that our sampling units were independent.

The local small-mammal assemblage did indeed select microhabitats (Table I), with associations between most species and habitats (ANOVA: $\mathrm{Q}=159.57, \mathrm{p}=0.003$ ). The difference between microhabitat utilisation was higher comparing ground versus understorey sites (all tests were significant at $\mathrm{p}<0.01$ except one with $\mathrm{p}<0.05$ ), but there was also a distinct segregation between microhabitats exclusively on the ground (ground litter versus ground fern, $\mathrm{p}=0.03$ ). The understorey microhabitats were used evenly by arboreal and scansorial small mammals, with no difference between them (Table II).

The CA between small-mammal species and microhabitats revealed that the first two axes accounted for $60.3 \%$ of the total variation, with $32.8 \%$ for the first and $27.5 \%$ for the second axis. Axis 1 was associated with ground-understorey differences, and axis 2 with internal differences in the understorey. There was a strong relationship between S. angouya and microhabitats of liana and simple-trunk tree. Akodon montensis was correlated with all microhabitats on the ground, but mainly with small ferns. Didelphis albiventris was more generally associated with several microhabitats, but mainly with fallen logs and Piper sp. shrubs. There was a reasonable association of $O$. nigripes and ground-litter and forked-tree microhabitats. The mouse-opossum G. microtarsus was associated with all microhabitats sampled in the understorey, though always weakly (Fig. 1).

In the test that compared the environmental variables measured on the ground habitats, only the variable "fern" differed between them, being more abundant only in the fern microhabitat 
TABLE I

Number of captures (number of individuals in parentheses) of small mammals in microhabitats sampled in deciduous Atlantic Forest on the Morro do Elefante, Santa Maria, southern Brazil.

\begin{tabular}{|c|c|c|c|c|c|c|c|c|}
\hline \multirow{2}{*}{ Species } & \multicolumn{8}{|c|}{ Microhabitat } \\
\hline & Fallen log & Liana & Simple tree & Forked tree & Ferns & Litter & Piper sp. & Total \\
\hline \multicolumn{9}{|l|}{ Rodents } \\
\hline Akodon montensis & 28 & - & - & - & 40 & 12 & 20 & $100(47)$ \\
\hline Mus musculus & 1 & - & - & - & - & - & - & $1(1)$ \\
\hline Oligoryzomys nigripes & - & - & 2 & - & - & 2 & - & $4(4)$ \\
\hline Sooretamys angouya & 1 & 6 & 1 & 3 & - & 1 & - & $12(10)$ \\
\hline \multicolumn{9}{|l|}{ Marsupials } \\
\hline Didelphis albiventris & 7 & - & - & 1 & 5 & 2 & 7 & $22(11)$ \\
\hline Gracilinanus microtarsus & - & 2 & 1 & 1 & - & 1 & - & $5(2)$ \\
\hline
\end{tabular}

TABLE II

Results of Analysis of Variance (ANOVA) via randomisation and contrasts between pairs of microhabitats sampled to capture small mammals in deciduous Atlantic Forest on the Morro do Elefante, Santa Maria, southern Brazil. * $p<0.05, * * p<0.01$.

\begin{tabular}{|c|c|c|}
\hline Microhabitat & Sum of squares & $\mathrm{p}$ \\
\hline \multicolumn{3}{|l|}{ Understorey } \\
\hline Liana $\mathrm{x}$ Forked Tree & 1.50 & 0.204 \\
\hline Liana $x$ Simple Tree & 0.55 & 0.611 \\
\hline Simple Tree x Forked Tree & 0.45 & 0.853 \\
\hline \multicolumn{3}{|l|}{ Ground/Understorey } \\
\hline Fallen $\log x$ Liana & 43.15 & $0.001 * *$ \\
\hline Fallen log x Simple Tree & 41.95 & $0.001 * *$ \\
\hline Fallen $\log$ x Forked Tree & 41.30 & $0.001 * *$ \\
\hline Liana $x$ Ferns & 82.70 & $0.001 * *$ \\
\hline Liana x Litter & 9.45 & $0.002 * *$ \\
\hline Liana x Piper sp. & 24.45 & $0.001 * *$ \\
\hline Simple Tree x Ferns & 81.50 & $0.001 * *$ \\
\hline Simple Tree x Litter & 7.45 & $0.012 *$ \\
\hline Simple Tree x Piper sp. & 22.75 & $0.002 * *$ \\
\hline Forked Tree x Ferns & 81.05 & $0.001 * *$ \\
\hline Forked Tree x Litter & 7.90 & $0.008 * *$ \\
\hline Forked Tree x Piper sp. & 22.30 & $0.002 * *$ \\
\hline \multicolumn{3}{|l|}{ Ground } \\
\hline Fallen $\log$ x Ferns & 7.45 & 0.415 \\
\hline Fallen $\log x$ Litter & 14.40 & 0.135 \\
\hline Fallen log x Piper sp. & 3.30 & 0.650 \\
\hline Ferns x Litter & 39.95 & $0.029 *$ \\
\hline Ferns x Piper sp. & 20.25 & 0.161 \\
\hline Fallen log x Piper sp. & 4.70 & 0.469 \\
\hline Total & 159.57 & $0.003 * *$ \\
\hline
\end{tabular}




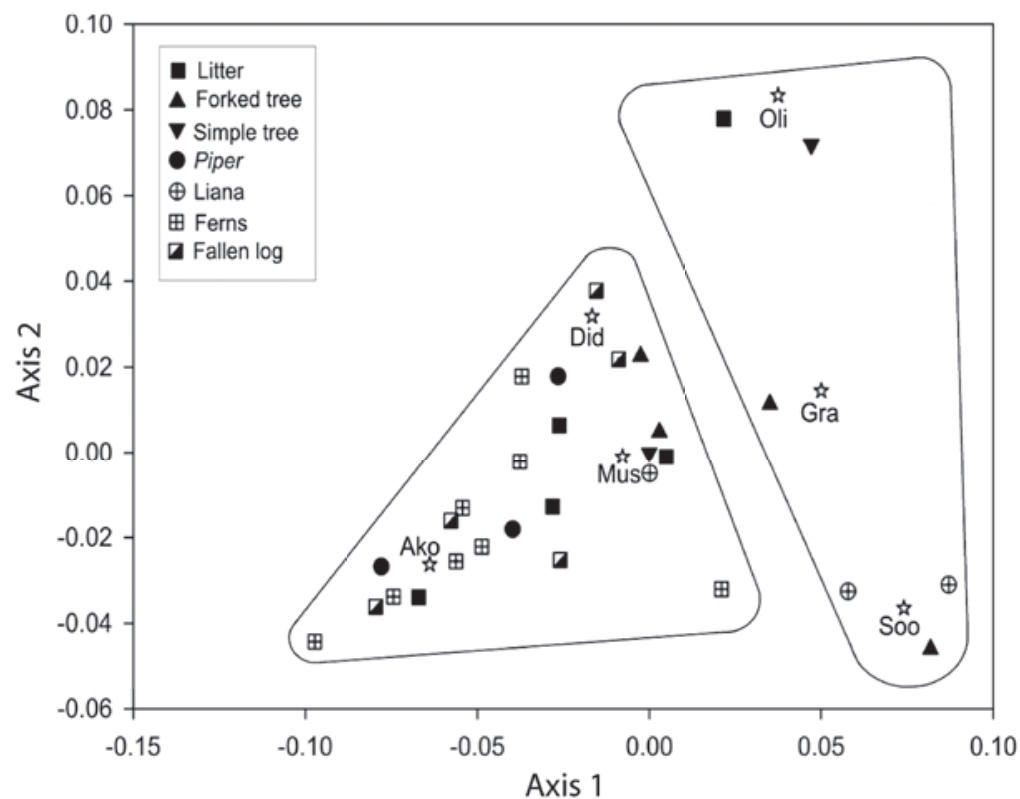

Figure 1 - Correspondence analysis showing associations between small mammal species and ground and understorey microhabitats in deciduous Atlantic Forest on the Morro do Elefante, Santa Maria, southern Brazil. The first axis corresponds to $32.8 \%$ of the variation, and the second axis to $27.5 \%$. Ako $=$ Akodon montensis; Oli = Oligoryzomys nigripes; Soo = Sooretamys angouya $;$ Mus = Mus musculus; Did = Didelphis albiventris; Gra = Gracilinanus microtarsus.

$(\mathrm{H}=13.42, \mathrm{p}=0.003)$, as was expected from our visual characterisation. For measures of litter, there was only a tendency to a lower density in sites with ferns, and a higher density in sites with shrubs (Table III).

TABLE III

Mean, standard deviation, and p-value for the KruskalWallis test between environmental variables measured in microhabitats on the ground in deciduous Atlantic Forest on the Morro do Elefante, Santa Maria, southern Brazil. $* \mathbf{p}>0.05$. $n$ is abundance of ferns or seedlings. Number of sampling units was 10 for each test.

\begin{tabular}{cccc}
\hline & \multicolumn{3}{c}{ Environmental Variables } \\
\hline Microhabitat & Litter $(\mathrm{g})$ & Fern $(\mathrm{n})$ & Seedling $(\mathrm{n})$ \\
\hline Ferns & $128 \pm 46$ & $35 \pm 15$ & $15 \pm 10$ \\
Fallen log & $184 \pm 115$ & $8 \pm 10$ & $17 \pm 11$ \\
$\begin{array}{c}\text { Ground litter } \\
\text { Piper sp. } \\
\text { shrub }\end{array}$ & $189 \pm 43$ & $18 \pm 17$ & $24 \pm 17$ \\
\hline $\begin{array}{c}\text { Kruskal- } \\
\text { Wallis }\end{array}$ & $\mathrm{p}=0.075$ & $\mathrm{p}=0.004^{*}$ & $\mathrm{p}=0.537$ \\
\hline
\end{tabular}

There was a positive and significant correlation between $D$. albiventris and $A$. montensis $(\mathrm{r}=0.83$; $\mathrm{p}=0.022$ ), but an inverse relationship between D. albiventris and $G$. microtarsus $(\mathrm{r}=-0.90 ; \mathrm{p}=$ 0.006). Hence, A. montensis showed an inverse relationship with $G$. microtarsus $(\mathrm{r}=-0.83 ; \mathrm{p}=$ 0.021 ). In the understorey, $S$. angouya showed a positive correlation with $G$. microtarsus $(\mathrm{r}=0.87$; $\mathrm{p}=0.011)$.

\section{DISCUSSION}

The present study provided new information about small mammals of the Atlantic Forest, revealing a well-structured community exhibiting resource partitioning. Besides, there was strong evidence of habitat selection in order to diminish predation, such as the case of $A$. montensis (see below).

Akodon montensis was the most abundant species in the study area, and was collected in all ground-based microhabitats, in agreement with its 
known, predominantly terrestrial habit (Cademartori et al. 2002, Vieira and Monteiro-Filho 2003). This species used significantly more microhabitats containing small ferns, which is thought to be related to avoidance of predation. In this case, ferns will help to conceal the rodent from predators when foraging. In Chile, A. olivaceous (Waterhouse, 1837) is associated with environmental variables such as sites with closed canopy (Murúa and González 1982). Similarly, the canopy cover was the most important variable for $A$. montensis in a mixed forest in Brazil, being possibly related to avoidance of aerial predation (Dalmagro and Vieira 2005), or providing a suitable microclimate for this species. The density of herbaceous vegetation is the most important variable for A. cursor (Winge, 1887), A. toba (Thomas, 1921) and A. azarae (Fischer, 1829) in the Atlantic Forest, Chaco and Pampa, respectively (Gentile and Fernandez 1999, Yahnke 2006, Sponchiado et al. 2012). These are congeneric species of $A$. montensis, and our results are in agreement with these later ones. Herbaceous vegetation and small ferns would play equivalent roles for the protection of individuals of Akodon during their activity periods. Considering that different scales are involved in these comparative approaches, canopy cover, herbaceous vegetation, and small ferns should be related to small mammal species at different scales (see Leiner et al. 2010). The first scale is possibly related to microclimate regulation, providing conditions for adequate metabolic regulation (such as body temperature), whereas the last two must play more important roles in protection against predation. Herbaceous vegetation and ferns will affect food availability only secondarily, since these areas contain food items that are usually consumed by small mammals, such as soil invertebrates. The strong tendency for sites with a high density of small ferns to contain a low density of litter (Table III) reinforces our hypothesis that $A$. montensis is avoiding predation, since it would be expected that this species would be found more frequently in places with high litter density, because it feeds mainly on litter arthropods (Casella and Cáceres 2006). Then, we hypothesise that A. montensis uses suboptimal sites in food resources in order to avoid predation in richer sites not protected by herbs (e.g. see Stagner and Zentall 2010); in the other hand, predators of A. montensis will search actively in these sites with abundance of herbs on the soil (see below).

Didelphis albiventris, although considered a generalist (Cáceres 2002, Alho 2005), used ground-based microhabitats more frequently and was scarcer in places with litter only. This species used the same microhabitats as A. montensis, and there was a positive correlation between the two species. This may be related to $D$. albiventris probably actively searching for this rodent species, particularly among dense ferns and fallen logs, since opossums are predators of species of Akodon (Cáceres and Monteiro-Filho 2001, Cáceres 2002, Moura et al. 2009). Didelphis albiventris also used microhabitats containing shrubs of the genus Piper sp. with more frequency, which was expected since this species consumes fruits of this genus at a regular basis (Cáceres 2002). Fruits of Piper sp. are consumed by bats (Fleming 1988) and small terrestrial mammals (Talamoni et al. 1999, Horn et. al. 2008, Casella and Cáceres 2006). The latter must climb the plant to access the fruits, which are held on the end of stems, as observed for $O$. nigripes here (personal observation) and elsewhere (Cáceres and Moura 2003). Didelphis albiventris must perceive the environment on a different scale than the other smallmammal species in the study area, because of its large body size (averaging $1 \mathrm{~kg}$ versus 20 to $100 \mathrm{~g}$ for the remaining species), besides its role as a predator of these species (Fonseca and Robinson 1990).

Sooretamys angouya was found in the understorey using lianas most frequently, and was recorded only once on the ground, whereas $O$. nigripes was found on tree trunks but also on the ground, in agreement with studies that have reported a scansorial mode of life for these 
species (Cademartori et al. 2003, Graipel et al. 2003b). In fact, $S$. angouya was revealed as more arboreal in our study area. So, our data suggest some spatial segregation among understorey species. This segregation, however, is weak if we take into consideration the positive correlation between $S$. angouya and $G$. microtarsus. The coexistence of these species would be facilitated by their differences in body size (100 g versus $30 \mathrm{~g}$, respectively) and possibly their feeding habits ( $G$. microtarsus is mostly an insectivore, and $S$. angouya is a frugivore-granivore; Fonseca et al. 1996, Martins and Bonato 2004). However, G. microtarsus is a more arboreal species than S. angouya (Vieira and Monteiro-Filho 2003) sometimes using the high stratum of the forest (Graipel 2003).

It has been reported that small terrestrial mammal species in mixed forest are more likely to partition the resource rather than compete for it (Dalmagro and Vieira 2005). Studies on marsupial ecomorphology have indicated that utilisation of substrata differing in inclination and diameter of the trunk and stems requires different morphological adaptations (Vieira 2006). Gracilinanus microtarsus, $O$. nigripes, and $S$. angouya differ in the shape of their long tails, and in the long length of their legs, particularly for the rodents. Such morphological differences may partly explain our results for habitat selection in the understorey, besides differences of body size (Mallmann et al. 2011).

We also recorded the non-native species, M. musculus, but we cannot draw any conclusion about its habitat selection since we capture a single specimen. The negative impact that exotic species may cause in the native fauna is well known (Lowe et al. 2000), and we highlight the associated risk of diseases transmission and competition with the native assemblage (e.g. Crowl et al. 2008, Fass and Weckerly 2010).

The present community of small mammals showed differences in habitat utilisation on the ground and in the understorey. Akodon montensis and $D$. albiventris showed terrestrial habits in the study area and tended to overlap each other in certain microhabitats, with a probable interaction of predation between them. Presumably to diminish predation, A. montensis selected locations with a high density of herbaceous vegetation. The remaining species used partially (O. nigripes) or predominantly the understorey, with some similarity in habitat selection between $S$. angouya and $G$. microtarsus. More refined researches on the vertical and horizontal use of space among small-mammal species are necessary, like the present research, in order to find more accurately associations between a species and its realized niche.

\section{ACKNOWLEDGMENTS}

Our thanks to colleagues from the Laboratório de Ecologia e Biogeografia of the UFSM for help in the fieldwork, especially Arielli F. Machado and Franchesco D. Flora; Conselho Nacional de Desenvolvimento Científico e Tecnológico (CNPq) and the Fundo de Amparo à Pesquisa do Rio Grande do Sul (FAPERGS) for financial support, and J.W. Reid reviewed the text for English correction. NCC is a CNPq-research fellow in Brazil.

\section{RESUMO}

Cada espécie animal pode apresentar seletividade por micro-habitats priorizando proteção, forrageio ou microclima. Para compreender os padrões de distribuição de pequenos mamíferos ao nível do solo e de sub-bosque, nós analisamos o uso de micro-habitat por pequenos mamíferos em uma floresta estacional no sul do Brasil. Dez estações amostrais com sete pontos de captura foram usadas para amostragem dos seguintes microhabitats: liana, tronco caído, solo apenas coberto por folhiço, solo coberto por samambaias, árvore com tronco simples, árvore com bifurcações e arbustos do gênero Piper sp.. Sete fases de campo foram executadas durante oito dias consecutivos de setembro de 2006 a janeiro de 2008. Quatro espécies de roedores (Akodon 
montensis, Sooretamys angouya, Oligoryzomys nigripes e Mus musculus) e duas espécies de marsupiais (Didelphis albiventris e Gracilinanus microtarsus) foram capturadas. As espécies capturadas apresentaram diferença significativa quanto ao uso do microhabitat (ANOVA $\mathrm{p}=0,003)$, particularmente entre locais no solo e sub-bosque. Akodon montensis utilizou com maior frequência samambaias terrestres e troncos caídos, $S$. angouya lianas, D. albiventris troncos caídos e Piper sp. e G. microtarsus árvores e lianas. Nós demonstramos que a comunidade de pequenos mamíferos locais, de fato, apresenta uma seleção de microhabitats, com associações entre a maioria das espécies e habitats. Além disso, há forte indício de seleção de habitat devido à pressão de predação.

Palavras-chave: roedores cricetídeos, marsupiais didelfídeos, seleção de habitat, relação predador-presa, uso vertical do espaço.

\section{REFERENCES}

ALHO C. 2005. Intergradation of habitats of non-volant small mammals in the patchy Cerrado landscape. Arq Mus Nac 63(1): 41-48.

Bergallo HG. 1990. Fatores determinantes do tamanho da área de vida em mamíferos. Ciênc Cul 42: 1067-1072.

CÁCERES NC. 2002. Food habits and seed dispersal by the whiteeared opossum, Didelphis albiventris, in southern Brazil. Stud Neotrop Fauna E 37: 97-104.

CÁCERES NC, GHIZONI-JÚNIOR IR AND GRAIPEL ME. 2002. Diet of two marsupials, Lutreolina crassicaudata and Micoureus paraguayanus, in a coastal Atlantic Forest island of Brazil. Mammalia 66(3): 331-340.

CÁCERES NC AND MonTeIro-FILHO ELA. 2001. Food habits, home range and activity of Didelphis aurita (Mammalia, Marsupialia) in a forest fragment of Southern Brazil. Stud Neotrop Fauna E 36(2): 85-92.

CÁCERES NC AND MOURA MO. 2003. Fruit removal of a wild tomato, Solanum granulosoleprosum Dunal (Solanaceae), by birds, bats and non-flying mammals in an urban Brazilian environment. Rev Bras Zoo 20: 519-522.

Cademartori CV, Marques RV and Pacheco SM. 2003. Contribuição ao conhecimento de roedores ocorrentes em floresta com araucárias. Comun Mus Cienc Tecno PUCRS 8: 23-30.

Cademartori CV, Marques RV, Pacheco SM, Baptista LR DE M AND GARCIA M. 2002. Roedores ocorrentes em floresta ombrófila mista (São Francisco de Paula, Rio grande do Sul) e a caracterização de seu hábitat. Comun Mus Cienc Tecno PUCRS 15: 61-86.
CAMPos C, OJEDA R, MONGE S AND DACAR M. 2001. Utilization of food resources by small and medium-sized mammals in the Monte Desert biome, Argentina. Austral Ecol 26(2): 142-149.

CASELlA J AND CÁCERES NC. 2006. Diet of four small mammal species from Atlantic forest patches in Southern Brazil. Neotrop Biol Conserv 1: 5-11.

Crowl tA, Crist TO, PARMenter RR, Belovsky G AND LUGO AE. 2008. The spread of invasive species and infectious disease as drivers of ecosystem change. Front Ecol Environ 6: 238-246.

CUnHa AA AND VIEIRA MV. 2004. Two bodies cannot occupy the same place at the same time, or the importance of space in the ecological niche. Bull Ecol Soc Am 85: 25-26.

DAlMagro AD AND VIEIRA EM. 2005. Patterns of habitat utilization of small rodents in an area of Araucaria forest in Southern Brazil. Austral Ecol 30: 353-362.

FALKENBERG JC AND ClARKE JA. 1998. Microhabitat use of deer mice: effects of interspecific interaction risks. $\mathrm{J}$ Mammal 79(2): 558-568.

FASS CJ AND WECKERLY FW. 2010. Habitat interference by Axis Deer on White-tailed Deer. J Wild Manage 74(4): 698-706.

FLEMING TH. 1988. The short-tailed fruit bat: a study in Plant-Animal Interactions. Chicago, The University of Chicago Press, 365 p.

Fonseca GAB, Hermann G, Leite YLR, MitTermeier RA, RYLANDS AB AND PATTON JL. 1996. Lista anotada dos mamíferos do Brasil. Occas Pap Conserv Biol 4: 1-38.

FonseCA GAB AND RobInSON JGR. 1990. Forest size and structure: competitive and predatory effects on small mammal communities. Biol Conserv 53: 265-294.

Freitas RR, DA Rocha PLB AND SiMÕes-Lopes PC. 2005. Habitat structure and small mammals abundances in one semiarid landscape in the Brazilian Caatinga. Rev Bras Zoo 22(1): 119-129.

Freitas SR, MORAEs DA, SANTORINI RT AND CERQUEIRA R. 1996. Habitat preference and food use by Metachirus nudicaudatus and Didelphis aurita (Didelphimorphia, Didelphidae) in a Restinga Forest at Rio de Janeiro. Rev Bras Biol 57: 93-98.

GENTILE R AND FERNANDEZ FAS. 1999. Influence of habitat structure on a streamside small mammal community in a Brazilian rural area. Mammalia 63: 29-40.

GRAIPEL ME. 2003. A simple ground-based method for trapping small mammals in the forest canopy. Mastozool Neotrop 10(1): 177-181.

GraiPel ME, Cherem JJ, Miller PRM AND Glock L. $2003 \mathrm{~b}$. Trapping small mammals in the forest understory: a comparison of three methods. Mammalia 67(4): 551-558.

GraiPEl ME, MiLler PRM AND GLOCK L. 2003a. Padrão de atividade de Akodon montensis e Oryzomys russatus na reserva Volta Velha, Santa Catarina, sul do Brasil. Mastozool Neotrop 10(2): 255-260.

HAMMER Ø, HARPER DAT AND RYAN PD. 2001. PAST: Paleontological Statistics Software Package for Education and Data Analysis. Palaeontologia Electronica, 49 p. 
HODARA K AND BUSCH M. 2010. Patterns of macro and microhabitat use of two rodent species in relation to agricultural practices. Ecol Res 25(1): 113-121.

HoRn GB, KINDEl A AND HARTZ SM. 2008. Akodon montensis (Thomas 1913) (Muridae) as a disperser of endozoohoric seeds in a coastal swamp forest in Southern Brazil. Mammal Biol 73: 325-329.

HUTCHINSON GE. 1957. Concluding remarks. Cold Spring Harbor Symp Quant Biol 22: 415-427.

LEINER NO, DickMAN CR AND SILVA WL. 2010. Multiscale habitat selection by slender opossums (Marmosops spp.) in the Atlantic forest of Brazil. J Mammal 91(3): 561-565.

LORENZI H. 2002. Árvores brasileiras - Manual de identificação e cultivo de plantas arbóreas nativas do Brasil. Quarta Edição. Nova Odessa, Instituto Plantarum Nova Odessa, 368 p.

Lowe S, Browne M, BoudJElas S AND DE POORTER M. 2000 100 of the World's Worst Invasive Alien Species a selection from the Global Invasive Species Database. IUCN Invasive Species Specialist Group (ISSG), 12 p.

MACHADO PFS AND LONGHI SJ. 1990. Aspectos florísticos e fitossociológicos do "Morro do Elefante", Santa Maria, RS. Rev Centro Cienc Rurais 20: 261-280.

mallmann A, Finokiet M, Dalmaso A, Melo GL, FERREIRA V AND CÁCERES NC. 2011. Dinâmica populacional e reprodução de pequenos mamíferos de floresta estacional do Maciço do Urucum, oeste do Pantanal, Brasil. Neotrop Biol Conser 6(2): 94-102.

MARTINS EG AND BONATO V. 2004. On the diet of Gracilinanus microtarsus (Marsupialia, Didelphidae) in an Atlantic Rainforest fragment in southeastern Brazil. Mammal Biol 69(1): 58-60.

Moreno JA. 1961. Clima do Rio Grande do Sul. Porto Alegre, Secretaria da Agricultura, $42 \mathrm{p}$.

MORRIS DW. 1987a. Ecological scales and habitat use. Ecology 68(2): 362-369.

MORRIS DW. 1987b. Test of density-dependent habitat selection in a patchy environment. Ecol Monogr 57(4): 269-281.

Moura MC, VieIRA MV AND CERQueIRA R. 2009. Occasional intraguild predation structuring small mammal assemblages: the marsupial Didelphis aurita in the Atlantic Forest of Brazil. Austral Ecol 34: 481-489.

MURÚA R AND GONZÁLEZ LA. 1982. Microhabitat selection in two Chilean cricetid rodents. Oecologia 52: 12-15.

OLIVEIRA-SANTOS LGR, TORTATO MA AND GRAIPEL ME. 2008. Activity pattern of Atlantic Forest small arboreal mammals as revealed by camera traps. J Trop Ecol 24(5): 563-567.

PILLAR VP. 2006. MULTIV, Multivariate exploratory analysis, randomisation testing and bootstrap resampling. User's guide v. 24. Porto Alegre, Universidade Federal do Rio Grande do Sul, Brazil.
PRICE M. 1978. The role of microhabitat in structuring desert rodent communities. Ecology 59(5): 624-626.

ROSENZWEIG ML. 1981. A theory of habitat selection. Ecology 62(2): 327-335

SCHOENER TW. 1974. Resource partitioning in ecological communities. Science 185: 27-39.

Sponchiado J, Melo GL AND CÁCERES NC. 2012. Habitat selection by small mammals in Brazilian Pampas biome. J Nat Hist 46(21-22): 1321-1335.

Stagner JP And Zentall TR. 2010. Suboptimal choice behavior in pigeons. Psychonomic Bulletin \& Reviews 17(13): 412-416.

STAPP P. 1997. Habitat selection by an insectivorous rodent: patterns and mechanisms across multiple scales. J Mammal 78(4): 1128-1143.

SuÁrez OV AND BonaVEnTURA SM. 2001. Habitat use and diet in sympatric species of rodents of low Paraná delta, Argentina. Mammalia 65: 167-176.

TALAMONI SA, COUTO D, LOPES MOG AND CORDEIRO Jr DA 1999. Dieta de algumas espécies de pequenos mamíferos do sudeste do Brasil. Bios 7: 51-56.

VIEIRA EM, IOB G, BRIANI DC AND PALMA ART. 2005. Microhabitat selection and daily movements of two rodents (Necromys lasiurus and Oryzomys scotti) in Brazilian Cerrado, as revealed by a spool-and-line device. Mammal Biol 70(6): 359-365.

VIEIRA EM AND MONTEIRO-FILHO ELA. 2003. Vertical stratification of small mammals in the Atlantic rain forest of south-eastern Brazil. J Trop Ecol 19: 501-507.

VIEIRA MV. 2006. Locomoção, morfologia e uso do habitat em marsupiais neotropicais: uma abordagem ecomorfológica. In: CÁCERES NC AND MONTEIRO-FILHO ELA (Eds), Os marsupiais do Brasil: Biologia, ecologia e evolução. Campo Grande, UFMS, p. 145-156.

WeKSLER M, PeRCEQUillo AR AND Voss RS. 2006. Ten new genera of Oryzomyine rodents (Cricetidae: Sigmodontinae). Am Mus Novit 3537: 1-29.

Wells K, Pfeiffer M, LAKIM MB AND Kalko EKV. 2006. Movement trajectories and habitat partitioning of small mammals in logged and unlogged rain forests on Borneo. J Animal Ecol 75: 1212-1223.

WILSON DE AND REEDER DM. 2005. Mammal species of the world. A taxonomic and geographic Reference. $3^{\text {rd }}$ ed., Johns Hopkins, University Press, 2142 p.

YAHNKE CJ. 2006. Habitat use and natural history of small mammals in the central Paraguayan Chaco. Mastozool Neotrop 13: 103-116. 